\title{
Dual renin-angiotensin system inhibition for prevention of renal and cardiovascular events: do the latest trials challenge existing evidence?
}

\author{
Samir G Mallat
}

\begin{abstract}
Circulatory and tissue renin-angiotensin systems (RAS) play a central role in cardiovascular (CV) and renal pathophysiology, making RAS inhibition a logical therapeutic approach in the prevention of CV and renal disease in patients with hypertension. The cardio- and renoprotective effects observed with angiotensin-converting enzyme (ACE) inhibitors or angiotensin II receptor blockers (ARBs) monotherapy, together with the availability of a direct renin inhibitor (DRI), led to the investigation of the potential benefits of dual RAS inhibition. In small studies, ARB and ACE inhibitor combinations were shown to be beneficial in patients with CV or renal disease, with improvement in surrogate markers. However, in larger outcome trials, involving combinations of ACE inhibitors, ARBs or DRIs, dual RAS inhibition did not show reduction in mortality in patients with diabetes, heart failure, coronary heart disease or after myocardial infarction, and was in fact, associated with increased harm. A recent meta-analysis of all major trials conducted over the past 22 years involving dual RAS inhibition has clearly shown that the risk-benefit ratio argues against the use of dual RAS inhibition. Hence, the recent evidence clearly advocates against the use of dual RAS inhibition, and single RAS inhibition appears to be the most suitable approach to controlling blood pressure and improving patient outcomes.
\end{abstract}

Keywords: Angiotensin-converting enzyme (ACE) inhibitors, Angiotensin II receptor blockers, Blood pressure, Cardiovascular disease, Dual renin-angiotensin system inhibition, Direct renin inhibitors, Outcomes, Renal disease

\section{Introduction}

The central role of the renin-angiotensin system (RAS) in the regulation of blood pressure $(\mathrm{BP})$ has been recognized for many years. The discovery of tissue-based angiotensin II production has resulted in the concept of a local RAS that is independent of the circulating RAS.

RAS activation following the release of renin by the kidney results in a cascade of physiological events (Figure 1). Renin catalyzes the formation of angiotensin I, which is then converted to angiotensin II by angiotensin-converting enzyme (ACE), resulting in activation of the angiotensin II receptors and its deleterious effect on renal vasculature, resulting in chronic kidney disease (CKD) [1-6]. The progressive development of cardiovascular (CV) disease (CVD) resulting from pathophysiological changes mediated by angiotensin II in the presence of risk factors is well

Correspondence: sm104@aub.edu.lb

Department of Internal Medicine, American University of Beirut Medical Center (AUBMC), PO Box 11-0236, Riad-El-Solh, Beirut 1107 2020, Lebanon established [2] and local activation of RAS in the vascular walls is thought to contribute to atherosclerosis [5]. Furthermore, intrarenal RAS is often inappropriately activated in diabetes and is thought to predispose these patients to nephropathy $[7,8]$. RAS inhibition (both circulatory and intrarenal) is therefore a key therapeutic approach to slow progression of CKD and to reduce $\mathrm{CV}$ risk through both BP-dependent and independent mechanisms.

All three classes of available RAS inhibitors (ACE inhibitors, angiotensin receptor blockers [ARBs] and direct renin inhibitors [DRIs]) interrupt the normal angiotensin II feedback suppression of renin secretion from the kidneys [10]. In the past two decades, landmark trials have shown that early aggressive lowering of BP and inhibition of the RAS improves outcomes for patients with renal disease or CVD [11-15]. ACE inhibitors and ARBs reduce proteinuria, slow progression of CKD and lower morbidity and mortality rates in patients at high CVD risk, and in 


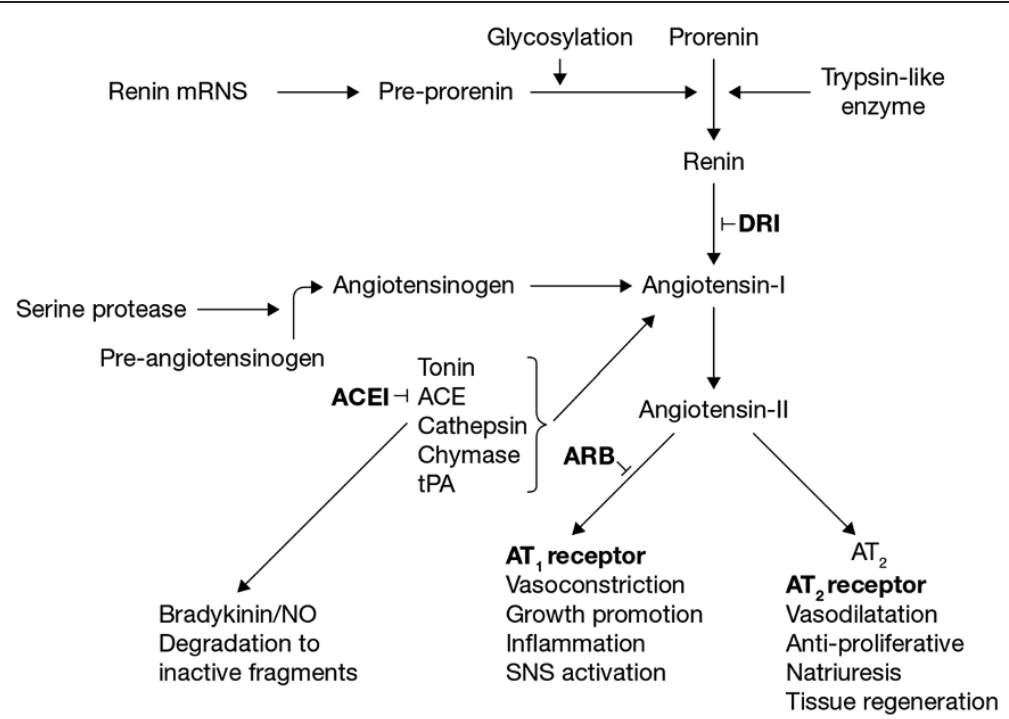

Figure 1 Schematic representation of the RAS. ACE, angiotensin-converting enzyme; ARB, angiotensin II receptor blocker; $\mathrm{AT}_{1}$, angiotensin II type 1 receptor; $\mathrm{AT}_{2}$, angiotensin II type 2 receptor; DRI, direct renin inhibitor; NO, nitric oxide; PRA, plasma renin activity; PRC, plasma renin concentration; RAS, renin-angiotensin system; SNS, sympathetic nervous system; tPA, tissue plasminogen activator. Adapted from Farsang 2011 [9].

patients already displaying evidence of target organ damage (TOD) such as myocardial infarction (MI), heart failure (HF), stable coronary heart disease (CHD) with or without left ventricular dysfunction (LVD), and reduce mortality and reinfarction rates in patients with LVD or HF after MI [12-32]. Evidence from large outcome trials such as the ONgoing Telmisartan Alone and in combination with Ramipril Global Endpoint Trial (ONTARGET ${ }^{\circ}$ ) suggests that ARBs like telmisartan have additional CV benefits beyond BP lowering [33]. Outcomes with ARB monotherapy in post-MI patients are similar to those achieved with high doses of an ACE inhibitor [28,34]. ACE inhibitors and ARBs are widely acknowledged to confer additional renoprotective benefits beyond the effects of $\mathrm{BP}$ control alone [35] (Table 1). ARBs are also known to activate peroxisome proliferator-activated receptor gamma (PPAR- $\gamma$ ), however, only telmisartan exhibits increased PPAR- $\gamma$ activity at therapeutic dosages [36,37]. PPAR- $\gamma$ enhances insulin sensitivity, has positive effects on lipid metabolism, endothelium, oxidative stress and vascular inflammation, and its anti-inflammatory, antiatherogenic and antihypertensive effects are considered to exert $\mathrm{CV}$ protective effects $[38,39]$. Initial data suggest that, as with ARBs and ACE inhibitors, aliskiren, an oral DRI, may protect against TOD [40-42].

Dual RAS inhibition was theorized to result in better RAS inhibition, giving rise to greater benefit on BP lowering and cardiorenal outcomes. Early studies on dual RAS inhibition with ACE inhibitors and ARBs have shown greater reduction in BP with the combination [51], but benefits on surrogate endpoints and outcomes have not been consistent [22,28,52-61]. The ONTARGET ${ }^{\circ}$ study, the largest trial of dual RAS inhibition in high-risk patients (those with CVD or diabetes but not HF), in which patients were randomized to receive either telmisartan or ramipril, or a combination of the two agents, found no evidence to support the use of dual RAS inhibition in these patients $[33,62]$. This article reviews the recent evidence, including those from large outcome trials (Table 2), for the efficacy of dual RAS inhibition in patients at a high risk of CVD with multiple co-morbidities such as LVD, HF, CKD and TOD.

\section{Study selection}

The PubMed database was systematically searched for English language articles published during the period May 2008 to May 2013, reporting results of trials comparing dual blockers of the RAS with monotherapy. The search terms used were "angiotensin-converting enzyme inhibitor", "angiotensin receptor blocker", "cardiovascular disease", "chronic kidney disease", "diabetes", "direct renin inhibitor", "dual RAS blockade", "heart failure", "myocardial infarction". The reference lists of the articles retrieved by the electronic search also were searched for other potentially eligible articles. This review also was supplemented with publications of landmark studies on single RAS inhibition that fell outside the search criteria.

\section{High-risk patients with LVD or HF}

A series of landmark trials with ACE inhibitors in patients with LVD or HF such as VALsartan in Acute myocardial INfarction (VALIANT), Valsartan in Heart Failure Trial (Val-HeFT) and others have reported reductions in $\mathrm{CV}$ 
Table 1 Renoprotective effects of ACE inhibitors and ARBs (large [n or > 100] randomized controlled studies)

\begin{tabular}{|c|c|c|}
\hline Study population & Treatment arms & $\begin{array}{l}\text { Main findings: statistically significant renoprotective } \\
\text { effect of ACE inhibitor/ARB versus comparator }\end{array}$ \\
\hline \multicolumn{3}{|l|}{ ACE inhibitor } \\
\hline IDDM patients with macroalbuminuria [17] & Captopril or placebo & $\begin{array}{l}48 \% \text { RR in doubling of serum creatinine; } 50 \% \text { RR of the combined } \\
\text { endpoint (death, dialysis and transplantation) }\end{array}$ \\
\hline T2DM patients with albuminuria [43] & Enalapril or placebo & $1 \%$ versus $13 \%$ decline in kidney function \\
\hline Nondiabetic patients with proteinuria [44] & Ramipril or placebo & $\begin{array}{l}\text { Lower decline in GFR ( } 0.53 \mathrm{ml} / \mathrm{min} \text { versus } 0.88 \mathrm{ml} / \mathrm{min} \text { ); RR in } \\
\text { doubling of baseline creatinine or ESRD }\end{array}$ \\
\hline T2DM patients [45] & Ramipril or placebo & $24 \%$ risk reduction in overt nephropathy \\
\hline T2DM patients [46] & Enalapril or nifedipine & $\begin{array}{l}\text { Greater reduction in albuminuria; } 23.8 \% \text { patients (versus 15.4\%) } \\
\text { reverted to normoalbuminuria; } 19.1 \% \text { patients (versus 30.8\%) } \\
\text { developed macroalbuminuria }\end{array}$ \\
\hline \multicolumn{3}{|l|}{ ARB } \\
\hline T2DM patients with nephropathy [13] & Losartan or placebo & $\begin{array}{l}16 \% \text { RR in doubling of serum creatinine concentration; } 28 \% \text { RR } \\
\text { in ESRD; significant reduction in proteinuria versus placebo }\end{array}$ \\
\hline Hypertensive T2DM with nephropathy [11] & Irbesartan or amlodipine or placebo & RR of doubling serum creatinine and of ESRD \\
\hline T2DM patients with nephropathy [15] & Irbesartan or placebo & $\begin{array}{l}\text { Reduction in the onset of diabetic nephropathy compared } \\
\text { with placebo }\end{array}$ \\
\hline T2DM patients [47] & Telmisartan or placebo & $\begin{array}{l}\text { RR in progression to overt nephropathy; reduced UACR; } \\
\text { increased microalbuminuria remission }\end{array}$ \\
\hline T2DM patients with hypertension [48] & Telmisartan or ramipril & $\begin{array}{l}\text { Both telmisartan and ramipril increase } \mathrm{NO} \text { activity of renal } \\
\text { endothelium which may preserve renal function }\end{array}$ \\
\hline CVD and T2DM patients [49] & Telmisartan or placebo & $\begin{array}{l}\text { Prevented increase in albuminuria ( } 32 \% \text { increase versus } 63 \% \\
\text { increase); however, telmisartan was associated with a greater } \\
\text { doubling of serum creatinine and decrease in estimated GFR, } \\
\text { although there was no difference in terms of renal outcome }\end{array}$ \\
\hline T2DM patients [50] & Valsartan or amlodipine & Greater reduction in urine albumin excretion ( $44 \%$ versus $8 \%$ ) \\
\hline
\end{tabular}

$A C E$, angiotensin-converting enzyme; $A R B$, angiotensin II receptor blocker; CVD, cardiovascular disease; ESRD, end-stage renal disease; GFR, glomerular filtration rate; IDDM, insulin-dependent diabetes mellitus; $N O$, nitric oxide; $R R$, risk reduction; $T 2 D M$, Type 2 diabetes mellitus; $U A C R$, urinary albumin-creatinine ratio.

mortality and morbidity [22,23,25,27,28,31,32]. Evidence for efficacy of ARB monotherapy in this patient group is provided by the Evaluation of Losartan In The Elderly (ELITE) I and II studies [29,30], Candesartan in Heart failure Assessment of Reduction in mortality and Morbidity (CHARM) [53,54,58,59], ONTARGET ${ }^{\circ}$ [33] and Telmisartan Randomized AssessmeNt Study in ACE-I iNtolerant subjects with cardiovascular Disease (TRANSCEND ) [70].

There is limited, but conflicting, evidence on the effects of dual RAS inhibition on mortality in patients with LVD or HF. The prevalence of left ventricular hypertrophy (LVH) was reduced by dual RAS inhibition in ONTARGET (odds ratio, 0.93; 95\% confidence interval (CI), 0.84 to $1.02 ; \mathrm{p}=0.12$ compared with ramipril). In a pilot study in 24 treatment-naive hypertensive patients with left ventricular (LV) concentric hypertrophy randomized to ramipril plus candesartan or ramipril plus lercanidipine, the decrease of LV mass and the improvement of diastolic function were significantly greater with ramipril plus candesartan, suggesting a greater antiremodelling effect [71]. A benefit of dual RAS inhibition, of telmisartan and ACE inhibitors was apparent in a small study $(n=332)$ in patients with end-stage renal disease (ESRD) in addition to $\mathrm{HF}$ and impaired left ventricular ejection fraction (LVEF). The dual therapy significantly improved the three primary outcomes of all-cause mortality (35.1\% versus $54.4 \%$; $\mathrm{p}<0.001$ ), CV mortality (30.3\% versus $43.7 \%$; $\mathrm{p}<0.001)$ and hospital admission for chronic HF $(33.9 \%$ versus 55.1\%; $\mathrm{p}<0.0001)$ compared with placebo [72]. In post-acute MI / percutaneous coronary intervention Japanese patients, treatment with half-dose combination of valsartan and trandolapril was observed to suppress LV remodelling more effectively than trandolapril alone [73]. The ALiskiren Left ventricular Assessment of hypertrophY (ALLAY) trial randomized 465 hypertensive overweight patients with $\mathrm{LVH}$ to aliskiren $300 \mathrm{mg}$, losartan $100 \mathrm{mg}$ or the combination for 9 months. The combination of aliskiren plus losartan was not significantly different from losartan for the primary outcome of reduction in LV mass [65]. In a subset of 136 patients who had plasma aldosterone concentration measured at baseline and study end, aliskiren, either alone or in combination, resulted in a significantly greater reduction from baseline to 9 months in plasma aldosterone than losartan alone, and the suppression of aldosterone was associated with reduction of $\mathrm{LVH}$, independently of the change in systolic blood pressure (SBP) [74]. 
Table 2 Overview of large outcome trials investigating dual RAS inhibition

\begin{tabular}{|c|c|c|c|c|c|}
\hline Study name or author & Study population & ACE inhibitor & ARB & DRI & $\begin{array}{l}\text { Impact of combined therapy } \\
\text { versus monotherapy }\end{array}$ \\
\hline ONTARGET $^{\circ}[33,63]$ & $\begin{array}{l}\text { Patients at high risk } \\
\text { of } C V \text { events }\end{array}$ & Ramipril & Telmisartan & & $\begin{array}{l}\text { No improvement in CV outcomes; } \\
\text { increased incidence of renal events } \\
\text { due to acute renal failure caused by } \\
\text { concomitant diseases (tumour, } \\
\text { pneumonia, severe diabetes and others) }\end{array}$ \\
\hline ALOFT [64] & HF & Standard therapy & & Aliskiren & $\begin{array}{l}\text { Addition of aliskiren to standard treatment } \\
\text { reduced NT-proBNP. Combined therapy } \\
\text { had no effect on UACR }\end{array}$ \\
\hline ALLAY [65] & $\begin{array}{l}\text { Hypertensive patient } \\
\text { with LVH }\end{array}$ & & Losartan & Aliskiren & $\begin{array}{l}\text { No additional benefit over and above } \\
\text { monotherapy }\end{array}$ \\
\hline ALTITUDE [66] & T2DM patients & Standard therapy & & Aliskiren & $\begin{array}{l}\text { Increased incidence of AEs in the } \\
\text { combination arm (including non-fatal } \\
\text { stroke, renal dysfunction, hyperkalaemia } \\
\text { and hypotension) }\end{array}$ \\
\hline AVOID [12] & T2DM patients & & Losartan & Aliskiren & $\begin{array}{l}\text { Significantly reduced UACR versus losartan } \\
\text { monotherapy }\end{array}$ \\
\hline ASPIRE [67] & Patients following acute Ml & Standard therapy & & Aliskiren & $\begin{array}{l}\text { Combined therapy did not further } \\
\text { attenuate left-ventricular remodelling }\end{array}$ \\
\hline ASTRONAUT [68] & $\begin{array}{l}\text { Haemodynamically stable, } \\
\text { hospitalizations for heart } \\
\text { failure patients }\end{array}$ & Standard therapy & & Aliskiren & $\begin{array}{l}\text { No reduction in } \mathrm{CV} \text { death or } \mathrm{HF} \\
\text { rehospitalization at } 6 \text { months or } \\
12 \text { months after discharge }\end{array}$ \\
\hline VA NEPHRON-D $[61,69]$ & $\begin{array}{l}\text { Patients with diabetes and } \\
\text { overt proteinuria }\end{array}$ & Lisinopril & Losartan & & $\begin{array}{l}\text { Terminated early due to greater number of } \\
\text { observed acute kidney injury events and } \\
\text { hyperkalaemia in the combination group }\end{array}$ \\
\hline
\end{tabular}

$A C E$, angiotensin-converting enzyme; $A E$, adverse event; $A R B$, angiotensin II receptor blocker; $A L L A Y$, ALiskiren Left ventricular Assessment of hypertrophY; ALOFT, ALiskiren Observation of heart Failure Treatment; ALTITUDE, ALiskiren Trial in Type 2 diabetes Using carDio-renal Endpoints; ASPIRE, Aliskiren Study in Post-MI Patients to Reduce rEmodeling; ASTRONAUT, The AliSkiren TRial ON Acute heart failure oUTcomes; AVOID, Aliskiren in the eValuation of prOteinuria in Diabetes; $C V$, cardiovascular; $H F$, heart failure; $L V H$, left ventricular hypertrophy; $M I$, myocardial infarction; $N T$-proBNP, N-terminal prohormone of brain natriuretic peptide; ONTARGET, ONgoing Telmisartan Alone and in combination with Ramipril Global Endpoint Trial; RAS, renin-angiotensin system; T2DM, Type 2 diabetes mellitus; $U A C R$, urine albumin-creatinine ratio; VA NEPHRON-D, Combination Angiotensin Receptor Blocker and Angiotensin-Converting Enzyme Inhibitor for Treatment of Diabetic Nephropathy.

Standard therapy: ALOFT and ASPIRE-ACE inhibitor (or ARB) and $\beta$-blocker; ALTITUDE-ACE inhibitor or ARB; ASTRONAUT-included diuretics, ACE inhibitors or ARBs, $\beta$-blockers and aldosterone blocking agents, unless contraindicated.

In the ALiskiren Observation of heart Failure Treatment (ALOFT) study, patients with stable HF, and treated with an ACE inhibitor (or ARB) and $\beta$-blocker were randomized to once-daily, double-blind treatment with aliskiren $150 \mathrm{mg}$ or placebo. After 3 months of treatment, plasma N-terminal prohormone of brain natriuretic peptide (NT-proBNP) was significantly reduced with aliskiren, suggesting favourable neurohumoral effects in heart failure [64]. These beneficial changes in neurohumoral biomarkers were observed regardless of concomitant mineralocorticoid treatment received by $33 \%$ of patients. The incidence of pre-specified adverse events (AEs) of renal dysfunction, symptomatic hypotension and hyperkalaemia was low, and not significantly different between aliskiren and placebo, irrespective of whether or not patients were receiving mineralocorticoid treatment [75].

A meta-analysis of trials comparing ACE inhibitors alone or in combination with ARBs in patients with LVD or HF showed an increased risk of developing any $\mathrm{AE}$, hypotension, worsening renal function and hyperkalaemia with combination therapy, suggesting ACE inhibitors should not be routinely used in combination with ARBs in patients with LVD [76]. A later meta-analysis of trials comparing ACE inhibitors with ACE inhibitors plus ARBs in patients with HF showed fewer hospital admissions for HF with combination therapy (with significant heterogeneity between included trials), but no difference for overall mortality, hospitalization for any reason and fatal or nonfatal MI. Also, patients on combination therapy had a higher risk of worsening renal function and symptomatic hypotension, and a higher rate of permanent discontinuation of trial medications [77].

The AliSkiren TRial ON Acute heart failure oUTcomes (ASTRONAUT) was a double-blind, placebo-controlled study in which haemodynamically stable hospitalized HF patients were randomly allocated a median 5 days after admission to receive $150 \mathrm{mg}$ (increased to $300 \mathrm{mg}$ as tolerated) of aliskiren or placebo daily, in addition to standard therapy, which was continued after discharge for a median 11.3 months. At randomization, patients $(\mathrm{n}=1639)$ were receiving diuretics $(95.9 \%), \beta$-blockers (82.5\%), ACE inhibitors or ARBs (84.2\%), and mineralocorticoid receptor antagonists (57.0\%). At 6 and 12 months, addition of aliskiren to standard therapy did not reduce 
the main outcome measures of $\mathrm{CV}$ death or HF rehospitalization. The rates of hyperkalaemia, hypotension and renal impairment / renal failure were higher in the aliskiren group compared with placebo [68]. In the CHARM study, the effects of candesartan in patients with low LVEF receiving ACE inhibitors (CHARM-Added), and patients intolerant to ACE inhibitors (CHARM-Alternative), deaths and hospital admissions for HF were reduced to a greater extent by candesartan than by standard antihypertensive treatment $[53,54]$. However, in patients with preserved LVF, candesartan did not significantly reduce $\mathrm{CV}$ mortality or hospitalizations for HF [54].

\section{High-risk patients with CKD / Proteinuria}

ACE inhibitors and ARBs are widely acknowledged to confer additional renoprotective benefits beyond the effects of BP control alone [35] (Table 1). Inhibition of the RAS slows the progression of renal disease in patients with diabetes, hypertension and albuminuria, but also decreases the risk of $\mathrm{CV}$ events $[15,17,45,78,79]$. Few trials have specifically evaluated the effects of dual RAS inhibition on mortality in patients with CKD. Instead, most studies have considered surrogate endpoints [80].

In the ONTARGET ${ }^{\circ}$ trial, dual RAS inhibition was associated with a greater risk for the composite outcome of dialysis, doubling of serum creatinine and death (compared with ramipril monotherapy) [63], even though the increase in urine albumin to creatinine ratio (relative to baseline) was less $(\mathrm{p}<0.001)$. Similarly, a post-hoc analysis of the ONTARGET ${ }^{\circ}$ and TRANSCEND trials that stratified patients by glomerular filtration rate (GFR) and albuminuria did not support dual RAS inhibition over single RAS inhibition in high vascular risk patients with low GFR or albuminuria [81]. A meta-analysis / metaregression of trials in patients with primary glomerulonephritis showed that the antiproteinuric response to ACE inhibitor plus ARB therapy versus either monotherapy is consistently greater and strictly related to baseline proteinuria, associated with only moderate increase in serum potassium levels and not peculiar to immunoglobulin A nephropathy [82]. In a retrospective analysis of 6-month data from 16 patients with a single kidney and proteinuria, dual RAS blockade with several different ACE inhibitors and ARBs at the maximal dose tolerated by the patient did not affect plasma creatinine levels or creatinine clearance, but also did not reduce proteinuria, suggesting lack of benefit in these patients [83]. In a meta-analysis of 49 randomized trials, which excluded the combination treatment of angiotensin-II receptor blocker and angiotensinconverting-enzyme inhibitor in non-diabetic renal disease (COOPERATE) trial (which was retracted due to serious concerns about the study data), monotherapy with ARBs and ACE inhibitors was reported to delay progression of proteinuria over both the short (1-4 months) and longer
(5-12 months) term [84]. Although the data were limited, the combination of the two drugs was considered to reduce proteinuria more than either drug alone [84].

In a small, randomized cross-over study, 22 patients with biopsy-proven immunoglobulin A (IgA) nephropathy and persistent proteinuria despite $A C E$ inhibitor or $A R B$, were randomized to either oral aliskiren $300 \mathrm{mg} /$ day or placebo for 16 weeks and then crossed over to the other treatment arm after a washout period. After aliskiren treatment, there was a significant reduction in proteinuria in 4 weeks, which remained at a low level throughout the treatment period. There was a significant difference in proteinuria between the aliskiren and placebo groups from 4 to 16 weeks after treatment. After aliskiren treatment, there were modest but statistically significant reductions in estimated GFR (eGFR) and diastolic BP. None of the patients developed severe hyperkalaemia (serum potassium $\geq 6.0 \mathrm{mmol} / \mathrm{l}$ ) during the study period [85]. In a randomized, opencontrolled, cross-over study performed in 18 whites with chronic nondiabetic proteinuric kidney disease, after 8 weeks' combination treatment with telmisartan $80 \mathrm{mg}$ and aliskiren $300 \mathrm{mg}$ (compared with the combination of telmisartan $80 \mathrm{mg}$ and eplerenone $50 \mathrm{mg}$ and telmisartan $160 \mathrm{mg}$ alone), the urinary excretion of transforming growth factor $\beta-1$ was stable, despite a significant increase in plasma renin concentration, and there were no differences in renal function and potassium serum level between the treatments. There were no episodes of hypotension and acute renal impairment. Adverse effects were not reported, suggesting that the combination therapy with telmisartan and aliskiren may be safe in young nondiabetic patients with I-II stage CKD at low vascular risk [86]. In a metaanalysis, combined treatment with an ACE inhibitor plus $\mathrm{ARB}$ was found to be more effective than monotherapy with an ACE inhibitor / ARB alone for reducing daily proteinuria in IgA nephropathy, without an increased risk of hyperkalaemia, but no improvement in GFR was observed [87].

In a retrospective cohort study of elderly patients in clinical practice, increased risks of adverse renal outcomes and hyperkalaemia were observed in those on combination therapy with an ACE inhibitor and ARB compared with those on monotherapy [88]. In day-to-day clinical practice, a multimodal strategy (Remission Clinic) of dual RAS inhibition with ACE inhibitors and ARBs up-titrated to maximum tolerated doses, intensified BP control, amelioration of dyslipidaemia by statins, smoking cessation and healthy lifestyle implementation, was found to safely and effectively achieve remission or regression of proteinuria and stabilize kidney function in most CKD patients with heavy proteinuria despite ACE inhibitor therapy, and almost fully prevent progression to ESRD [89]. In a community setting, retrospective cohort-based study, dual therapy with ACE inhibitor and ARB was associated with 
hyperkalaemia and a decrease in renal function. The absolute risks were especially high among patients with reduced baseline renal function [90].

In an open-label study, 47 patients with advanced CKD were block randomized to 16 weeks of monotherapy with increasing doses of RAS blockade aiming at enalapril $20 \mathrm{mg}$ once daily or candesartan $16 \mathrm{mg}$ once daily, followed by 5 weeks of combination therapy aiming at combined enalapril $20 \mathrm{mg}$ and candesartan $16 \mathrm{mg}$ for 3 weeks. Twenty-one patients (45\%) did not tolerate dual blockade due to unacceptable plasma creatinine increase, hypotension, general discomfort or unmanageable hyperkalaemia. Hyperkalaemia was reported in seven (15\%) patients [91]. In another open-label study, 67 CKD patients were randomized to 16 weeks of monotherapy with either enalapril or candesartan followed by 8 weeks of dual blockade aiming at a total dose of $16 \mathrm{mg}$ candesartan and $20 \mathrm{mg}$ enalapril once daily. Dual blockade resulted in significant BP-independent reductions in aortic pulse wave volume and in augmentation index compared with monotherapy. Furthermore, pulse pressure amplification was improved and central systolic BP was reduced [92]. In a prospective, 12-month study in patients with nondiabetic proteinuria, with normal or slightly impaired renal function, combination therapy with ramipril and valsartan was more efficacious than either monotherapy in reducing proteinuria and serum creatinine level in the first 3 (proteinuria and serum creatinine) or 6 (serum creatinine) months of treatment [93].

\section{High-risk patients with diabetes}

Diabetes mellitus is considered as a major risk factor for CVD [94], and CVD is the leading cause of death in Type 2 diabetes mellitus (T2DM) patients [95]. Guidelines recommend RAS inhibitors as the first monotherapy for diabetes patients with hypertension [96,97]. Landmark trials such as Action in Diabetes and Vascular Disease: Preterax and Diamicron MR Controlled Evaluation (ADVANCE) [98], Action to Control Cardiovascular Risk in Diabetes study [99], ONTARGET [33] and TRANSCEND $^{\circ}$ [70] have shown CV and renal benefits with ACE inhibitors or ARBs in patients with T2DM.

In ONTARGET, dual RAS inhibition was not found to be beneficial and was associated with increased harm. The ALiskiren Trial in Type 2 diabetes Using carDio-renal Endpoints (ALTITUDE) study evaluated the addition of aliskiren to an ACE inhibitor or an ARB in T2DM patients with CKD, CVD or both, but was stopped early due to safety concerns $[66,100]$. The study randomized 8,506 patients to aliskiren or placebo added to standard cardiorenal-protective treatment (an ACE inhibitor or an ARB). The trial was stopped early because, after the seventh interim review of data, the Data Monitoring Committee identified increased incidence of AEs (renal dysfunction, hyperkalaemia, hypotension and an excess of strokes) in patients in the aliskiren arm and concluded that patients were unlikely to benefit from aliskiren treatment added on top of standard antihypertensives [66]. The Combination Angiotensin Receptor Blocker and Angiotensin-Converting Enzyme Inhibitor for Treatment of Diabetic Nephropathy (VA NEPHRON-D) multicentre trial to assess the effect of the combination of losartan and lisinopril compared with losartan alone, on the progression of kidney disease in 1,850 patients with diabetes and overt proteinuria, was terminated recently for similar reasons to those of the ALTITUDE study $[61,69]$.

In the Aliskiren in the Evaluation of Proteinuria in Diabetes (AVOID) study, 599 patients with T2DM, hypertension and nephropathy were randomized to losartan or losartan plus aliskiren. After 6 months' treatment, the dual RAS inhibition treatment was associated with a $20 \%$ reduction in the mean urinary albumin-to-creatinine ratio compared with single RAS inhibition treatment $(\mathrm{p}<0.001)$. The mean rate of decline in eGFR was lower with dual RAS inhibition treatment, but not significantly different from single RAS inhibition treatment [12]. In a small, randomized, crossover trial study in 26 patients with T2DM, hypertension and albuminuria, dual RAS inhibition with aliskiren plus irbesartan was associated with a significantly greater reduction in albuminuria than either of the single RAS inhibition treatments (dual RAS inhibition, $71 \%$ reduction; aliskiren, $-48 \%$; irbesartan, $-58 \%$; $\mathrm{p}<0.001$ versus aliskiren; $\mathrm{p}=0.028$ versus irbesartan) [101].

In a recent post-hoc subgroup analysis of patients with diabetes, with or without nephropathy, from the ONTARGET $^{\circ}$ trial, it was observed that combination therapy with telmisartan plus ramipril did not increase the risk of stroke, other major $\mathrm{CV}$ or renal (dialysis or doubling of serum creatinine) outcomes compared with monotherapy, but the AEs of acute dialysis, hyperkalaemia and hypotension occurred more frequently with combination therapy [102]. In the Valsartan Aliskiren Hypertension Diabetes (VIvID) study, 1,143 hypertensive participants with T2DM and stage 1 or 2 CKD were randomized to receive combination aliskiren/valsartan 150/160 mg or valsartan $160 \mathrm{mg}$ monotherapy for 2 weeks, with forcetitration to $300 / 320 \mathrm{mg}$ and $320 \mathrm{mg}$, respectively, for another 6 weeks. Combination treatment had additive effects on BP reduction, and tolerability was similar to valsartan [103].

In an open-label, randomized, parallel-controlled study, 64 hypertensive patients with T2DM and CKD, on telmisartan $80 \mathrm{mg}$ plus amlodipine $5 \mathrm{mg}$ treatment, were allocated to receive either aliskiren $(150 \mathrm{mg}$ increased to $300 \mathrm{mg}$ ) or an increased dose of amlodipine $(10 \mathrm{mg})$. After 24 weeks, there was no significant difference between the two groups in BP decrease, serum creatinine levels or eGFR rate. However, plasma aldosterone levels were 
significantly decreased in the aliskiren group compared with the amlodipine group, and this decrease correlated significantly with the decrease in urinary 8-hydroxy-2' deoxyguanosine and liver-type fatty acid binding protein, suggesting that the addition of aliskiren to the maximal recommended dose of $\mathrm{ARB}$ and usual dose of amlodipine is more effective in reducing albuminuria and oxidant stress in hypertensive diabetic patients with CKD than increasing the dose of amlodipine [104].

\section{High-risk patients with a broad range of CV risk factors and TOD}

ONTARGET $^{\circ}$ was one of the largest trials conducted in over 25,000 patients at high CV risk (defined as those with coronary, peripheral or cerebrovascular disease, or diabetes with end-organ damage). The incidence of the primary endpoint (a composite of $\mathrm{CV}$ death, MI, stroke or hospitalization for HF) was similar in the dual and two single RAS inhibition groups after a median follow-up of 56 months. However, telmisartan was better tolerated, even in this population that had been screened for tolerance of ACE inhibitors. Compared with ramipril alone, telmisartan plus ramipril was associated with significantly higher incidences of hypotensive symptoms ( $4.8 \%$ versus $1.7 \%$; $\mathrm{p}<0.001)$, syncope $(0.3 \%$ versus $0.2 \% ; \mathrm{p}=0.03)$ and renal dysfunction (13.5\% versus 10.2\%; p < 0.001) [33]. The (AVANT GARDE)-TIMI 43 Trial recruited 1,101 stable patients post acute coronary syndrome having an increase in natriuretic peptides (NP) without heart failure or left ventricular dysfunction $<40 \%$. They were randomized to 8 weeks' treatment with aliskiren, valsartan, their combination or placebo, and there was no evidence for a benefit of early treatment initiation with valsartan, aliskiren or their combination compared with placebo [105].

A study in patients with MI, the Aliskiren Study in Post-MI patients to Reduce rEmodeling (ASPIRE) study, compared aliskiren with placebo as add on to standard therapy (an ACE inhibitor or ARB and a $\beta$-blocker) [67]. At the end of a 36-week treatment period, no difference was observed in the primary endpoint of end-systolic volume change (aliskiren, $-4.4 \pm 16.8 \mathrm{ml}$; placebo, $-3.5 \pm$ $16.3 \mathrm{ml} ; \mathrm{p}=0.44$ ). Furthermore, no differences in composite endpoint of $\mathrm{CV}$ death, hospitalization for $\mathrm{HF}$ or reduction in LVEF > 6 points were observed (aliskiren, 7\%; placebo, $6 \% ; \mathrm{p}=0.85$ ). Aliskiren added to standard therapy was associated with more AEs including hypotension, and increases in creatinine and hyperkalaemia. In 17 patients with coronary artery disease (CAD) and SBP >130 mmHg on ACE inhibitor or ARB therapy, addition of aliskiren $150 \mathrm{mg}$ for 6 weeks significantly reduced SBP and plasma renin activity but did not affect plasminogen activator inhibitor-1, fibrinogen, or D-dimer levels, suggesting that dual RAS inhibition does not have any effect on biomarkers of the fibrinolytic system [106].

\section{Discussion}

Chronic RAS inhibition using ACE inhibitors or ARBs as monotherapy is the standard of care to treat the vasoconstrictive / pro-inflammatory effects of RAS activation. Despite a strong biological rationale, dual RAS blockade has been largely disappointing, with initial benefits seen on surrogate endpoints [55] not being translated to meaningful superior clinical benefit [80]. Data from outcome trials such as ONTARGET ${ }^{\circ}$, VA NEPHRON-D, ALTITUDE and ASTRONAUT have shown no renal or CV outcome benefits with dual RAS inhibition, and have even shown deleterious effects across most patient groups. For ACE inhibitor / ARB dual therapy, benefits appear confined to symptomatic HF in patients whose symptoms persist in the presence of maximized ACE inhibitor and beta-blocker treatment and not immediately post-MI, and arguably in severe hypertension while balancing the potential adverse effects [107].

The ONTARGET trial was the first to allude to the need for caution over the use of dual RAS inhibition, even though the study was not designed to measure the impact of treatment on renal events [33]. A systematic review of $\mathrm{ARBs}$ and $\mathrm{ACE}$ inhibitors in ischaemic heart disease concluded that dual RAS inhibition with an ARB and ACE inhibitor is no better than ACE inhibitor or ARB therapy alone and increases the risk of harm [108]. Dual RAS blockade was not beneficial for clinically relevant endpoints in patients with diabetic nephropathy [109]. A systematic review of randomized controlled trials reported until 2009 also showed lack of evidence to support the use of combination therapy in people with albuminuria and one or more CV risk factors [110]. It is of interest that small studies have shown some benefits in the reduction of proteinuria with dual RAS blockers in primary glomerulopathy $[82,85]$.

Dual RAS inhibition studies involving aliskiren also have not shown consistent benefits but have reported increased harm with combination treatment. In patients with uncomplicated Type 1 diabetes, dual RAS blockade with aliskiren and ramipril was associated with greater arterial compliance, flow-mediated vasodilatation and renal vasodilatation [111]. The AVOID and ALTITUDE studies conducted in patients with diabetes and advanced CKD did not show beneficial effects of dual RAS inhibition involving aliskiren, while in the VIvID study conducted in patients with diabetes and early stages of CKD, the tolerability of combination therapy with aliskiren and valsartan was similar to valsartan monotherapy, although the study was of a short duration. A meta-analysis that assessed the combination of aliskiren with other RAS inhibitors reported an increased risk of hyperkalaemia (but not acute kidney injury) with combination treatment [112]. A post-hoc subgroup analysis of ONTARGET ${ }^{\circ}$ showed no increase in the risk of stroke, other major $\mathrm{CV}$ or renal outcomes in 
patients with diabetes with or without nephropathy [102], unlike the ALTITUDE trial results which suggested that use of aliskiren in combination with an ACE inhibitor or an ARB increased risk of stroke in people with diabetes [100]. However, in both studies, there was an increase in adverse renal events, suggesting dual RAS inhibition is not beneficial in these patients [102]. The VA NEPHRON-D trial was terminated recently for similar reasons to those of ALTITUDE $[69,113]$. A recent meta-analysis of 9 studies with 11,543 patients with diabetes showed that patients with diabetes receiving dual RAS blockade had a higher risk (versus monotherapy) of hyperkalaemia, hypotension and kidney damage, with no reduction in overall mortality. Except for kidney damage, removing the most influential study (ALTITUDE) from the analysis did not substantially alter the results of the analyses [114]. Hence, recent evidence suggests that these combinations should not be routinely prescribed in patients with diabetes until further data become available from other future studies [115].

Despite the lack of outcome evidence, dual RAS inhibition was recommended in several guidelines on the basis of changes in surrogate endpoints such as BP, proteinuria and endothelial dysfunction [116]. However, the clinical outcomes and safety data have not confirmed indications to dual RAS blockade in essential hypertension treatment, $\mathrm{HF}$ and ischaemic heart disease [117]. Existing evidence indicates that it is reasonable for continued use of ACE inhibitor plus ARB combination for proteinuric nephropathies and resistant hypertension [117], and for diabetic nephropathy [107]. Ongoing studies that may give further insight into the role of dual RAS inhibition are the Longterm Impact of RAS Inhibition on Cardiorenal Outcomes (LIRICO), and Aliskiren Trial of Minimizing OutcomeS for Patients with HEart failure (ATMOSPHERE) comparing aliskiren with aliskiren plus enalapril in patients with chronic HF. Multi-agent, low-level intervention earlier in the disease process is yet to be explored [107].

The Canadian Hypertension Education Program has recommended against use of ARBs and ACE inhibitors together except in patients with HF refractory to ACE inhibitor [118]. The American Heart Association guidelines currently do not recommend the use of ACE inhibitors and ARBs together, but there is no specific directive warning against their use in combination. The United States Food and Drug Administration also has not issued any warnings. In 2012, the National Healthcare Services professionals were advised to initiate combination of an ACE inhibitor and ARB only under specialist supervision in patients with renal disease, taking into account the potential for adverse effects such as hyperkalaemia [119]. Based on the ALTITUDE study results, dual aliskiren with ACE inhibitor/ARB therapy is now contraindicated by the US Food and Drug Administration in patients with diabetes and is to be avoided in patients with moderate renal impairment
(GFR $<60 \mathrm{ml} / \mathrm{min}$ ) [120], and is contraindicated by the European Medicines Agency (EMA) in patients with diabetes and in patients with moderate renal impairment $(\mathrm{GFR}<60 \mathrm{ml} / \mathrm{min})$ [121].

A recent systematic review and meta-analysis of all randomized controlled trials reported between January 1990 and August 2012 comparing dual blockers of the RAS with monotherapy, and reporting data on either long-term efficacy ( $\geq 1$ year) or safety events ( $\geq 4$ weeks), and with a sample size of at least 50 (68,405 patients [mean age 61 years, $71 \%$ men] and mean duration of 52 weeks) showed that although dual blockade of the RAS had seemingly beneficial effects on certain surrogate endpoints, it failed to reduce mortality and was associated with an excessive risk of AEs such as hyperkalaemia, hypotension and renal failure compared with monotherapy. The results of this most comprehensive meta-analysis to date indicated the risk-benefit ratio argues against the use of dual therapy [113]. Based on these study results, the EMA recently started a review of the risks of combining certain medicines to block separate stages of the RAS in the treatment of hypertension and congestive heart failure [122].

Selection of the most appropriate antihypertensive combination should be dependent on careful review of the individual patient and appropriate consideration of drug pharmacology. Existing evidence suggests that in $\mathrm{CV}$ high-risk patients and those with evidence of renal disease, the use of an ARB plus calcium channel blocker is the preferred combination due to superior renoprotective and $\mathrm{CV}$ benefits and reduced metabolic side effects in patients with concomitant metabolic disorders [123].

\section{Conclusions}

Although some small studies demonstrate benefits of combinations of ARBs with ACE inhibitors, larger clinical trials such as ONTARGET and VA NEPHRON-D indicate that this approach to dual RAS inhibition does not improve outcomes across most patient groups, and in fact, increases the risk of AEs. Similarly, dual RAS inhibition involving aliskiren has been reported in large trials such as ALTITUDE and ASTRONAUT to increase the risk of AEs with no clinical benefits. A recent meta-analysis of all major trials involving dual RAS inhibition has clearly shown that the risk-benefit ratio argues against the use of dual RAS inhibition. Based on these results, the EMA currently is reviewing the use of dual RAS blockade in the treatment of hypertension and congestive heart failure.

\section{Abbreviations}

ACE: Angiotensin-Converting Enzyme; AE: Adverse Event; ALLAY: ALiskiren

Left ventricular Assessment of HypertrophY; ALOFT: ALiskiren Observation of heart Failure Treatment; ALTITUDE: Aliskiren Trial in Type 2 Diabetes Using

Cardio-Renal Endpoints; ARB: Angiotensin II Receptor Blocker;

ASPIRE: Aliskiren Study in Post-MI patients to Reduce rEmodeling;

ASTRONAUT: AliSkiren TRial ON Acute heart failure oUTcomes; 
$A T_{1}$ : Angiotensin II Type 1 receptor; $A T_{2}$ : Angiotensin II Type 2 receptor; ATMOSPHERE: Aliskiren Trial of Minimizing Outcomes for Patients with HEart failuRE; (AVANT GARDE)-TIMI 43: Aliskiren and Valsartan to Reduce NT-proB-type natriuretic peptide (BNP) via Renin-Angiotensin-Aldosterone-System Blockade; AVOID: Aliskiren in the eValuation of prOteinuria in Diabetes; BP: Blood Pressure; CHARM: Candesartan in Heart failure Assessment of Reduction in Mortality and Morbidity; CHD: Coronary Heart Disease; Cl: Confidence Interval; CKD: Chronic Kidney Disease; COOPERATE: Combination Treatment of angiotensin II receptor blocker and Angiotensin-Converting Enzyme inhibitor in nondiabetic renal Disease; CV: Cardiovascular; CVD: Cardiovascular Disease; DRI: Direct Renin Inhibitor; ELITE: Evaluation of Losartan In The Elderly; EMA: European Medicines Agency; ESRD: End-Stage Renal Disease; eGFR: estimated Glomerular Filtration Rate; HF: Heart Failure; IDDM: Insulin-Dependent Diabetes Mellitus; IgA: Immunoglobulin A; LIRICO: Long-term Impact of RAS Inhibition on Cardiorenal Outcomes; LVD: Left Ventricular Dysfunction; LVEF: Left Ventricular Ejection Fraction; LVH: Left Ventricular Hypertrophy; MI: Myocardial Infarction; NT-proBNP: N-terminal Prohormone of Brain Natriuretic Peptide; NO: Nitric Oxide; ONTARGET ${ }^{\circ}$ : ONgoing Telmisartan Alone and in combination with Ramipril Global Endpoint Trial; PRA: Plasma Renin Activity; PRC: Plasma Renin Concentration; PPAR- $\gamma$ : Peroxisome Proliferator-Activated Receptor Gamma; RAS: Renin Angiotensin System; RR: Risk Reduction; SNS: Sympathetic Nervous System; T2DM: Type 2 diabetes mellitus; TOD: Target Organ Damage; tPA: tissue Plasminogen Activator; TRANSCEND : Telmisartan Randomized AssessmeNt Study in ACE-I iNtolerant subjects with cardiovascular Disease; UACR: Urinary Albumin-Creatinine Ratio; Val-HeFT: Valsartan in Heart Failure Trial; VALIANT: VALsartan in Acute myocardial iNfarcTion; VA NEPHRON-D: Combination Angiotensin Receptor Blocker and Angiotensin-Converting Enzyme Inhibitor for Treatment of Diabetic Nephropathy; VIVID: Valsartan Aliskiren Hypertension Diabetes.

\section{Competing interests}

The author declares that he has no competing interests.

\section{Author's contributions}

SM was fully responsible for all content and editorial decisions, was involved at all stages of the manuscript (including concept development and critical review and revision of the article), and has approved the final version of the review that reflects the author's interpretation and conclusions.

\section{Author's information}

SM is Associate Professor of Clinical Medicine and Director of the End-Stage Renal Disease Program in the Division of Nephrology and Hypertension, Department of Internal Medicine, at the American University of Beirut Medical Center.

\section{Acknowledgements}

Medical writing assistance, supported financially by Boehringer Ingelheim Pharma GmbH \& Co. KG., was provided by Aruna Jeans and Chris Langford, of PAREXEL, during the preparation of this review. Boehringer Ingelheim Pharma GmbH \& Co. KG., was given the opportunity to check the data used in the review for factual accuracy only. Aside from financial support for medical writing assistance, no other funding has been provided for this manuscript.

Received: 2 March 2013 Accepted: 15 July 2013

Published: 19 July 2013

\section{References}

1. Brewster UC, Perazella MA: The renin-angiotensin-aldosterone system and the kidney: effects on kidney disease. Am J Med 2004, 116(4):263-272.

2. Dzau V, Braunwald E: Resolved and unresolved issues in the prevention and treatment of coronary artery disease: a workshop consensus statement. Am Heart J 1991, 121 (4 Pt 1):1244-1263.

3. Fliser D: Perspectives in renal disease progression: the endothelium as a treatment target in chronic kidney disease. J Nephrol 2010, 23(4):369-376.

4. Hunyady L, Catt KJ: Pleiotropic AT1 receptor signaling pathways mediating physiological and pathogenic actions of angiotensin II. Mol Endocrinol 2006, 20(5):953-970.

5. Sata M, Fukuda D: Crucial role of renin-angiotensin system in the pathogenesis of atherosclerosis. J Med Invest 2010, 57(1-2):12-25.
6. Siragy HM, Carey RM: Role of the intrarenal renin-angiotensin-aldosterone system in chronic kidney disease. Am J Nephrol 2010, 31(6):541-550.

7. Hollenberg NK, Price DA, Fisher ND, Lansang MC, Perkins B, Gordon MS, Williams $\mathrm{GH}$, Laffel LM: Glomerular hemodynamics and the renin-angiotensin system in patients with type 1 diabetes mellitus. Kidney Int 2003, 63(1):172-178.

8. Taniwaki H, Ishimura E, Kawagishi T, Matsumoto N, Hosoi M, Emoto M, Shoji T, Shoji S, Nakatani T, Inaba M, Nishizawa Y: Intrarenal hemodynamic changes after captopril test in patients with type 2 diabetes: a duplex Doppler sonography study. Diabetes Care 2003, 26(1):132-137.

9. Farsang C: Indications for and utilization of angiotensin receptor II blockers in patients at high cardiovascular risk. Vasc Health Risk Manag 2011, 7:605-622.

10. Staessen JA, Li Y, Richart T: Oral renin inhibitors. Lancet 2006, 368(9545):1449-1456.

11. Lewis EJ, Hunsicker LG, Clarke WR, Berl T, Pohl MA, Lewis JB, Ritz E, Atkins $R C$, Rohde R, Raz I: Renoprotective effect of the angiotensin-receptor antagonist irbesartan in patients with nephropathy due to type 2 diabetes. N Engl J Med 2001, 345(12):851-860.

12. Parving $H H$, Persson F, Lewis JB, Lewis EJ, Hollenberg NK: Aliskiren combined with losartan in type 2 diabetes and nephropathy. N Engl J Med 2008, 358(23):2433-2446.

13. Brenner BM, Cooper ME, de Zeeuw D, Keane WF, Mitch WE, Parving $\mathrm{HH}_{\text {, }}$ Remuzzi G, Snapinn S, Zhang Z, Shahinfar S: Effects of losartan on renaland cardiovascular outcomes in patients with type 2 diabetes and nephropathy. N Engl J Med 2001, 345:861-869.

14. Gaede $\mathrm{P}$, Lund-Andersen $\mathrm{H}$, Parving HH, Pedersen O: Effect of a multifactorial intervention on mortality in type 2 diabetes. $N$ Engl J Med 2008, 358(6):580-591.

15. Parving HH, Lehnert $H$, Brochner-Mortensen J, Gomis R, Andersen S, Arner P: The effect of irbesartan on the development of diabetic nephropathy in patients with type 2 diabetes. N Engl J Med 2001, 345(12):870-878.

16. Basi S, Fesler P, Mimran A, Lewis JB: Microalbuminuria in type 2 diabetes and hypertension: a marker, treatment target, or innocent bystander? Diabetes Care 2008, 31(Suppl 2):S194-S201.

17. Lewis EJ, Hunsicker LG, Bain RP, Rohde RD: The effect of angiotensinconverting-enzyme inhibition on diabetic nephropathy. The Collaborative Study Group. N Engl J Med 1993, 329(20):1456-1462.

18. Parving $H \mathrm{H}$, Hovind $\mathrm{P}$ : Microalbuminuria in type 1 and type 2 diabetes mellitus: evidence with angiotensin converting enzyme inhibitors and angiotensin II receptor blockers for treating early and preventing clinical nephropathy. Curr Hypertens Rep 2002, 4(5):387-393.

19. Strippoli GF, Craig MC, Schena FP, Craig JC: Role of blood pressure targets and specific antihypertensive agents used to prevent diabetic nephropathy and delay its progression. J Am Soc Nephrol 2006, 17(4 Suppl 2):S153-S155.

20. AIRE study investigators: Effect of ramipril on mortality and morbidity of survivors of acute myocardial infarction with clinical evidence of heart failure. The Acute Infarction Ramipril Efficacy (AIRE) Study Investigators. Lancet 1993, 342(8875):821-828.

21. Braunwald E, Domanski MJ, Fowler SE, Geller NL, Gersh BJ, Hsia J, Pfeffer MA, Rice MM, Rosenberg YD, Rouleau JL: Angiotensin-converting-enzyme inhibition in stable coronary artery disease. N Engl J Med 2004, 351(20):2058-2068

22. Cohn JN, Johnson G, Ziesche S, Cobb F, Francis G, Tristani F, Smith R, Dunkman WB, Loeb H, Wong M: A comparison of enalapril with hydralazine-isosorbide dinitrate in the treatment of chronic congestive heart failure. N Engl J Med 1991, 325(5):303-310

23. CONSENSUS study investigators: Effects of enalapril on mortality in severe congestive heart failure. Results of the Cooperative North Scandinavian Enalapril Survival Study (CONSENSUS). The CONSENSUS Trial Study Group. N Engl J Med 1987, 316(23):1429-1435.

24. Fox KM: Efficacy of perindopril in reduction of cardiovascular events among patients with stable coronary artery disease: randomised, double-blind, placebo-controlled, multicentre trial (the EUROPA study). Lancet 2003, 362(9386):782-788.

25. Kober L, Torp-Pedersen C, Carlsen JE, Bagger H, Eliasen P, Lyngborg K, Videbaek J, Cole DS, Auclert L, Pauly NC: A clinical trial of the angiotensinconverting-enzyme inhibitor trandolapril in patients with left ventricular dysfunction after myocardial infarction. Trandolapril Cardiac Evaluation (TRACE) Study Group. N Engl J Med 1995, 333(25):1670-1676.

26. Maggioni AP: Measuring the occurrence of myocardial infarction. Eur Heart J 1999, 20(9):634-635. 
27. Pfeffer MA, Braunwald E, Moye LA, Basta L, Brown EJ Jr, Cuddy TE, Davis BR, Geltman EM, Goldman S, Flaker GC: Effect of captopril on mortality and morbidity in patients with left ventricular dysfunction after myocardial infarction. Results of the survival and ventricular enlargement trial. The SAVE Investigators. N Engl J Med 1992, 327(10):669-677.

28. Pfeffer MA, McMurray JJ, Velazquez EJ, Rouleau JL, Kober L, Maggioni AP, Solomon SD, Swedberg K, Van de WF, White H, Leimberger JD, Henis M, Edwards S, Zelenkofske S, Sellers MA, Califf RM: Valsartan, captopril, or both in myocardial infarction complicated by heart failure, left ventricular dysfunction, or both. N Engl J Med 2003, 349(20):1893-1906.

29. Pitt B, Segal R, Martinez FA, Meurers G, Cowley AJ, Thomas I, Deedwania PC, Ney DE, Snavely DB, Chang PI: Randomised trial of losartan versus captopril in patients over 65 with heart failure (Evaluation of Losartan in the Elderly Study, ELITE). Lancet 1997, 349(9054):747-752.

30. Pitt B, Poole-Wilson PA, Segal R, Martinez FA, Dickstein K, Camm AJ, Konstam MA, Riegger G, Klinger GH, Neaton J, Sharma D, Thiyagarajan B: Effect of losartan compared with captopril on mortality in patients with symptomatic heart failure: randomised trial-the Losartan Heart Failure Survival Study ELITE II. Lancet 2000, 355(9215):1582-1587.

31. SOLVD investigators: Effect of enalapril on survival in patients with reduced left ventricular ejection fractions and congestive heart failure. The SOLVD Investigators. N Engl J Med 1991, 325(5):293-302.

32. SOLVD study investigators: Effect of enalapril on mortality and the development of heart failure in asymptomatic patients with reduced left ventricular ejection fractions. The SOLVD Investigattors. N Engl J Med 1992, 327(10):685-691.

33. Yusuf S, Teo KK, Pogue J, Dyal L, Copland I, Schumacher H, Dagenais G, Sleight $P$, Anderson C: ONTARGET Investigators. Telmisartan, ramipril, or both in patients at high risk for vascular events. N Engl J Med 2008, 358(15):1547-1559.

34. Dickstein K, Kjekshus J: Effects of losartan and captopril on mortality and morbidity in high-risk patients after acute myocardial infarction: the OPTIMAAL randomised trial. Optimal Trial in Myocardial Infarction with Angiotensin II Antagonist Losartan. Lancet 2002, 360(9335):752-760.

35. Taal MW, Brenner BM: Renoprotective benefits of RAS inhibition: from ACEI to angiotensin II antagonists. Kidney Int 2000, 57(5):1803-1817.

36. Kintscher $U$, Unger T: Vascular protection in diabetes: a pharmacological view of angiotensin II type 1 receptor blockers. Acta Diabetol 2005, 42(Suppl 1):S26-S32

37. Munger MA: Use of angiotensin receptor blockers in cardiovascular protection: current evidence and future directions. P T 2011, 36(1):22-40.

38. Halabi CM, Sigmund CD: Peroxisome proliferator-activated receptorgamma and its agonists in hypertension and atherosclerosis: mechanisms and clinical implications. Am J Cardiovasc Drugs 2005 5(6):389-398.

39. Verges B: Clinical interest of PPARs ligands. Diabetes Metab 2004, 30(1):7-12.

40. Trimarchi H: Role of aliskiren in blood pressure control and renoprotection. Int J Nephrol Renovasc Dis 2011, 4:41-48.

41. Kelly DJ, Zhang Y, Moe G, Naik G, Gilbert RE: Aliskiren, a novel renin inhibitor, is renoprotective in a model of advanced diabetic nephropathy in rats. Diabetologia 2007, 50(11):2398-2404.

42. Pilz B, Shagdarsuren E, Wellner M, Fiebeler A, Dechend R, Gratze P, Meiners S, Feldman DL, Webb RL, Garrelds IM, Jan Danser AH, Luft FC, Muller DN: Aliskiren, a human renin inhibitor, ameliorates cardiac and renal damage in double-transgenic rats. Hypertension 2005, 46(3):569-576.

43. Ravid M, Savin H, Jutrin I, Bental T, Katz B, Lishner M: Long-term stabilizing effect of angiotensin-converting enzyme inhibition on plasma creatinine and on proteinuria in normotensive type II diabetic patients. Ann Intern Med 1993, 118(8):577-581.

44. Randomised placebo-controlled trial of effect of ramipril on decline in glomerular filtration rate and risk of terminal renal failure in proteinuric, non-diabetic nephropathy. The GISEN Group (Gruppo Italiano di Studi Epidemiologici in Nefrologia). Lancet 1997, 349(9069):1857-1863.

45. Effects of ramipril on cardiovascular and microvascular outcomes in people with diabetes mellitus: results of the HOPE study and MICROHOPE substudy. Heart Outcomes Prevention Evaluation Study Investigators. Lancet 2000, 355(9200):253-259.

46. Chan C, Poulter N, Scanlon M, Whitehouse A, Welsh P, Sattar N, Sever P, on behalf of the ASCOT investigators: The Anglo-Scandinavian Cardiac Outcomes Trial (ASCOT) biomarker programme. J Hypertens 2011, 29:e17-e18.
47. Makino H, Haneda M, Babazono T, Moriya T, Ito S, Iwamoto Y, Kawamori R, Takeuchi M, Katayama S: Prevention of transition from incipient to overt nephropathy with telmisartan in patients with type 2 diabetes. Diabetes Care 2007, 30(6):1577-1578

48. Schmieder RE, Delles C, Mimran A, Fauvel JP, Ruilope LM: Impact of telmisartan versus ramipril on renal endothelial function in patients with hypertension and type 2 diabetes. Diabetes Care 2007, 30(6):1351-1356.

49. Mann JF, Schmieder RE, Dyal L, McQueen MJ, Schumacher H, Pogue J, Wang X, Probstfield JL, Avezum A, Cardona-Munoz E, Dagenais GR, Diaz R, Fodor G, Maillon JM, Ryden L, Yu CM, Teo KK, Yusuf S: Effect of telmisartan on renal outcomes: a randomized trial. Ann Intern Med 2009, 151(1):1-2.

50. Viberti G, Wheeldon NM: Microalbuminuria reduction with valsartan in patients with type 2 diabetes mellitus: a blood pressure-independent effect. Circulation 2002, 106(6):672-678.

51. Doulton TW, He FJ, MacGregor GA: Systematic review of combined angiotensin-converting enzyme inhibition and angiotensin receptor blockade in hypertension. Hypertension 2005, 45(5):880-886.

52. Bakris GL, Ruilope L, Locatelli F, Ptaszynska A, Pieske B, de Champlain J, Weber MA, Raz I: Treatment of microalbuminuria in hypertensive subjects with elevated cardiovascular risk: results of the IMPROVE trial. Kidney Int 2007, 72(7):879-885.

53. Granger CB, McMurray JJ, Yusuf S, Held P, Michelson EL, Olofsson B, Ostergren J, Pfeffer MA, Swedberg K: Effects of candesartan in patients with chronic heart failure and reduced left-ventricular systolic function intolerant to angiotensin-converting-enzyme inhibitors: the CHARMAlternative trial. Lancet 2003, 362(9386):772-776.

54. McMurray JJ, Ostergren J, Swedberg K, Granger CB, Held P, Michelson EL, Olofsson B, Yusuf S, Pfeffer MA: Effects of candesartan in patients with chronic heart failure and reduced left-ventricular systolic function taking angiotensin-converting-enzyme inhibitors: the CHARM-Added trial. Lancet 2003, 362(9386):767-771.

55. Messerli FH: The sudden demise of dual renin-angiotensin system blockade or the soft science of the surrogate end point. J Am Coll Cardiol 2009, 53(6):468-470.

56. Messerli FH, Staessen JA, Zannad F: Of fads, fashion, surrogate endpoints and dual RAS blockade. Eur Heart J 2010, 31(18):2205-2208.

57. Mogensen CE, Neldam S, Tikkanen I, Oren S, Viskoper R, Watts RW, Cooper ME: Randomised controlled trial of dual blockade of renin-angiotensin system in patients with hypertension, microalbuminuria, and non-insulin dependent diabetes: the candesartan and lisinopril microalbuminuria (CALM) study. BMJ 2000, 321(7274):1440-1444.

58. Pfeffer MA, Swedberg K, Granger CB, Held P, McMurray JJ, Michelson EL, Olofsson B, Ostergren J, Yusuf S, Pocock S: Effects of candesartan on mortality and morbidity in patients with chronic heart failure: the CHARM-Overall programme. Lancet 2003, 362(9386):759-766.

59. Yusuf S, Pfeffer MA, Swedberg K, Granger CB, Held P, McMurray JJ, Michelson EL, Olofsson B, Ostergren J: Effects of candesartan in patients with chronic heart failure and preserved left-ventricular ejection fraction: the CHARM-Preserved Trial. Lancet 2003, 362(9386):777-781.

60. Epstein M: Re-examining RAS-blocking treatment regimens for abrogating progression of chronic kidney disease. Nat Clin Pract Nephrol 2009, 5(1):12-13.

61. Fried LF, Duckworth W, Zhang JH, O'Connor T, Brophy M, Emanuele N, Huang GD, McCullough PA, Palevsky PM, Seliger S, Warren SR, Peduzzi P: Design of combination angiotensin receptor blocker and angiotensinconverting enzyme inhibitor for treatment of diabetic nephropathy (VA NEPHRON-D). Clin J Am Soc Nephrol 2009, 4(2):361-368.

62. Volpe M, Danser AH, Menard J, Waeber B, Mueller DN, Maggioni AP, Ruilope $L M$ : Inhibition of the renin-angiotensin-aldosterone system: is there room for dual blockade in the cardiorenal continuum? J Hypertens 2012, 30(4):647-654.

63. Mann JF, Schmieder RE, McQueen M, Dyal L, Schumacher H, Pogue J, Wang X, Maggioni A, Budaj A, Chaithiraphan S, Dickstein K, Keltai M, Metsarinne K, Oto A, Parkhomenko A, Piegas LS, Svendsen TL, Teo KK, Yusuf S: Renal outcomes with telmisartan, ramipril, or both, in people at high vascular risk (the ONTARGET study): a multicentre, randomised, double-blind, controlled trial. Lancet 2008, 372(9638):547-553.

64. McMurray JJ, Pitt B, Latini R, Maggioni AP, Solomon SD, Keefe DL, Ford J, Verma A, Lewsey J: Effects of the oral direct renin inhibitor aliskiren in patients with symptomatic heart failure. Circ Heart Fail 2008, 1(1):17-24. 
65. Solomon SD, Appelbaum E, Manning WJ, Verma A, Berglund T, Lukashevich $V$, Cherif PC, Smith BA, Dahlof B: Effect of the direct renin inhibitor aliskiren, the angiotensin receptor blocker losartan, or both on left ventricular mass in patients with hypertension and left ventricular hypertrophy. Circulation 2009, 119(4):530-537.

66. McMurray JJ, Abraham WT, Dickstein K, Kober L, Massie BM, Krum H: Aliskiren, ALTITUDE, and the implications for ATMOSPHERE. Eur J Heart Fail 2012, 14(4):341-343.

67. Solomon SD, Shin SH, Shah A, Skali H, Desai A, Kober L, Maggioni AP, Rouleau JL, Kelly RY, Hester A, McMurray JJ, Pfeffer MA: Effect of the direct renin inhibitor aliskiren on left ventricular remodelling following myocardial infarction with systolic dysfunction. Eur Heart J 2011, 32(10):1227-1234

68. Gheorghiade M, Bohm M, Greene SJ, Fonarow GC, Lewis EF, Zannad F, Solomon SD, Baschiera F, Botha J, Hua TA, Gimpelewicz CR, Jaumont X, Lesogor A, Maggioni AP: Effect of aliskiren on postdischarge mortality and heart failure readmissions among patients hospitalized for heart failure: the ASTRONAUT randomized trial. JAMA 2013, 309(11):1125-1135.

69. National PBM Bulletin: Dual renin-angiotensin aldosterone system blockade in diabetic nephropathy and increased adverse events; 2013. December 2; Available at: URL: [http://www.pbm.va.gov/vacenterformedicationsafety/ nationalpbmbulletin/DualRenin-AngiotensinAldosteroneSystem BlockadeandlmpairedRenalFu.pdf]

70. Yusuf S, Teo K, Anderson C, Pogue J, Dyal L, Copland I, Schumacher H, Dagenais $G$, Sleight $P$ : Effects of the angiotensin-receptor blocker telmisartan on cardiovascular events in high-risk patients intolerant to angiotensin-converting enzyme inhibitors: a randomised controlled trial. Lancet 2008, 372(9644):1174-1183.

71. Grandi AM, Solbiati F, Laurita E, Maresca AM, Nicolini E, Marchesi C, Gianni $M$, Guasti L, Venco A: Effects of dual blockade of renin-angiotensin system on concentric left ventricular hypertrophy in essential hypertension: a randomized, controlled pilot study. Am J Hypertens 2008, 21(2):231-237

72. Cice G, Di Benedetto A, D'Isa S, D'Andrea A, Marcelli D, Gatti E, Calabro R: Effects of telmisartan added to angiotensin-converting enzyme inhibitors on mortality and morbidity in hemodialysis patients with chronic heart failure a double-blind, placebo-controlled trial. J Am Coll Cardiol 2010, 56(21):1701-1708.

73. Miyazaki S, Kasai T, Miyauchi K, Miyazaki T, Akimoto Y, Takagi A, Aihara K, Kawamura M, Suwa S, Kojima S, Sumiyoshi M, Daida H: Changes of matrix metalloproteinase-9 level is associated with left ventricular remodeling following acute myocardial infarction among patients treated with trandolapril, valsartan or both. Circ J 2010, 74(6):1158-1164.

74. Pouleur AC, Uno H, Prescott MF, Desai A, Appelbaum E, Lukashevich V, Smith BA, Dahlof B, Solomon SD: Suppression of aldosterone mediates regression of left ventricular hypertrophy in patients with hypertension. J Renin Angiotensin Aldosterone Syst 2011, 12(4):483-490.

75. Pitt B, Latini R, Maggioni AP, Solomon SD, Smith BA, Wright M, Prescott MF, McMurray JJ: Neurohumoral effects of aliskiren in patients with symptomatic heart failure receiving a mineralocorticoid receptor antagonist: the Aliskiren Observation of Heart Failure Treatment study. Eur J Heart Fail 2011, 13(7):755-764.

76. Lakhdar R, Al-Mallah MH, Lanfear DE: Safety and tolerability of angiotensin-converting enzyme inhibitor versus the combination of angiotensin-converting enzyme inhibitor and angiotensin receptor blocker in patients with left ventricular dysfunction: a systematic review and meta-analysis of randomized controlled trials. J Card Fail 2008, 14(3):181-188

77. Kuenzli A, Bucher HC, Anand I, Arutiunov G, Kum LC, McKelvie R, Afzal R, White $M$, Nordmann AJ: Meta-analysis of combined therapy with angiotensin receptor antagonists versus ACE inhibitors alone in patients with heart failure. PLoS One 2010, 5(4):e9946.

78. Yusuf S, Sleight P, Pogue J, Bosch J, Davies R, Dagenais G: Effects of an angiotensin-converting-enzyme inhibitor, ramipril, on cardiovascular events in high-risk patients. The Heart Outcomes Prevention Evaluation Study Investigators. N Engl J Med 2000, 342(3):145-153.

79. Basevi V, Di Mario S, Morciano C, Nonino F, Magrini N: Standards of medical care in diabetes-2011. Diabetes Care 2011, 34(Suppl 1):S11-S61.

80. Krause MW, Fonseca VA, Shah SV: Combination inhibition of the renin-angiotensin system: is more better? Kidney Int 2011, 80(3):245-255.
81. Tobe SW, Clase CM, Gao P, McQueen M, Grosshennig A, Wang X, Teo KK, Yusuf S, Mann JF: Cardiovascular and renal outcomes with telmisartan, ramipril, or both in people at high renal risk: results from the ONTARGET and TRANSCEND studies. Circulation 2011, 123(10):1098-1107.

82. Catapano F, Chiodini P, De Nicola L, Minutolo R, Zamboli P, Gallo C, Conte $\mathrm{G}$ : Antiproteinuric response to dual blockade of the renin-angiotensin system in primary glomerulonephritis: meta-analysis and metaregression. Am J Kidney Dis 2008, 52(3):475-485.

83. Robles NR, Ruiz JB, Hernandez GR, Ruiz-Calero R, Sanchez CE, Cubero JJ: Dual renin-angiotensin system blockade: in patients with single functioning kidney and proteinuria. Eur J Intern Med 2009, 20(2):186-189.

84. Kunz R, Friedrich C, Wolbers M, Mann JF: Meta-analysis: effect of monotherapy and combination therapy with inhibitors of the renin angiotensin system on proteinuria in renal disease. Ann Intern Med 2008, 148(1):30-48.

85. Szeto CC, Kwan BC, Chow KM, Leung CB, Li PK: The safety and short-term efficacy of aliskiren in the treatment of immunoglobulin a nephropathy a randomized cross-over study. PLoS One 2013, 8(5):e62736.

86. Lizakowski S, Tylicki L, Rutkowski P, Renke M, Sulikowska B, Heleniak Z, Donderski R, Bednarski R, Przybylska M, Manitius J, Rutkowski B: Safety of the enhanced renin-angiotensin-aldosteron system blockade with aliskiren in nondiabetic patients with chronic kidney disease. Pol Arch Med Wewn 2013, 123(5):221-227. Epub Apr 25

87. Cheng J, Zhang X, Tian J, Li Q, Chen J: Combination therapy an ACE inhibitor and an angiotensin receptor blocker for IgA nephropathy: a meta-analysis. Int J Clin Pract 2012, 66(10):917-923.

88. McAlister FA, Zhang J, Tonelli M, Klarenbach S, Manns BJ, Hemmelgarn BR: The safety of combining angiotensin-converting-enzyme inhibitors with angiotensin-receptor blockers in elderly patients: a population-based longitudinal analysis. CMAJ 2011, 183(6):655-662.

89. Remission Clinic Task Force: The Remission Clinic approach to halt the progression of kidney disease. J Nephrol 2011, 24(3):274-281.

90. Kurnik D, Vesterman-Landes J, Bialik M, Katzir I, Lomnicky Y, Halkin H, Loebstein R: Hyperkalemia and renal function during monotherapy and dual renin-angiotensin blockade in the community setting. Clin Ther 2011, 33(4):456-464.

91. Frimodt-Moller M, Hoj NA, Strandgaard S, Kamper AL: Feasibility of combined treatment with enalapril and candesartan in advanced chronic kidney disease. Nephrol Dial Transplant 2010, 25(3):842-847.

92. Frimodt-Moller M, Kamper AL, Strandgaard S, Kreiner S, Nielsen AH: Beneficial effects on arterial stiffness and pulse-wave reflection of combined enalapril and candesartan in chronic kidney disease-a randomized trial. PLoS One 2012, 7(7):e41757.

93. Bilic M, Munjas-Samarin R, Ljubanovic D, Horvatic I, Galesic K: Effects of ramipril and valsartan on proteinuria and renal function in patients with nondiabetic proteinuria. Coll Antropol 2011, 35(4):1061-1066.

94. Laakso M, Lehto S: Epidemiology of risk factors for cardiovascular disease in diabetes and impaired glucose tolerance. Atherosclerosis 1998, 137(Suppl):S65-S73.

95. Morrish NJ, Wang SL, Stevens LK, Fuller JH, Keen H: Mortality and causes of death in the WHO Multinational Study of Vascular Disease in Diabetes. Diabetologia 2001, 44(Suppl 2):S14-S21.

96. Mancia G, De Backer G, Dominiczak A, Cifkova R, Fagard R, Germano G, Grassi G, Heagerty AM, Kjeldsen SE, Laurent S, Narkiewicz K, Ruilope L, Rynkiewicz A, Schmieder RE, Boudier HA, Zanchetti A, Vahanian A, Camm J, De Caterina R, Dean V, Dickstein K, Filippatos G, Funck-Brentano C, Hellemans I, Kristensen SD, McGregor K, Sechtem U, Silber S, Tendera M, Widimsky P, Zamorano JL, Erdine S, Kiowski W, Agabiti-Rosei E, Ambrosioni E, Lindholm LH, Viigimaa M, Adamopoulos S, Agabiti-Rosei E, Ambrosioni E, Bertomeu V, Clement D, Erdine S, Farsang C, Gaita D, Lip G, Mallion JM, Manolis AJ, Nilsson PM, O'Brien E, Ponikowski P, Redon J, Ruschitzka F, Tamargo J, van ZP, Waeber B, Williams B: 2007 Guidelines for the Management of Arterial Hypertension: The Task Force for the Management of Arterial Hypertension of the European Society of Hypertension (ESH) and of the European Society of Cardiology (ESC). J Hypertens 2007, 25(6):1105-1187.

97. Mancia G, Laurent S, Agabiti-Rosei E, Ambrosioni E, Burnier M, Caulfield MJ, Cifkova R, Clement D, Coca A, Dominiczak A, Erdine S, Fagard R, Farsang C, Grassi G, Haller H, Heagerty A, Kjeldsen SE, Kiowski W, Mallion JM, Manolis A, Narkiewicz K, Nilsson P, Olsen MH, Rahn KH, Redon J, Rodicio J, Ruilope L, Schmieder RE, Struijker-Boudier HA, Van Zwieten PA, Viigimaa M, Zanchetti A: Reappraisal of European guidelines on hypertension management: a European Society of Hypertension Task Force document. Blood Press 2009, 18(6):308-347. 
98. Ninomiya T, Perkovic V, de Galan BE, Zoungas S, Pillai A, Jardine M, Patel A Cass A, Neal B, Poulter N, Mogensen CE, Cooper M, Marre M, Williams B, Hamet P, Mancia G, Woodward M, Macmahon S, Chalmers J: Albuminuria and kidney function independently predict cardiovascular and renal outcomes in diabetes. J Am Soc Nephrol 2009, 20(8):1813-1821.

99. Ginsberg HN, Elam MB, Lovato LC, Crouse JR III, Leiter LA, Linz P, Friedewald WT, Buse JB, Gerstein HC, Probstfield J, Grimm RH, Ismail-Beigi F, Bigger JT, Goff DC Jr, Cushman WC, Simons-Morton DG, Byington RP: Effects of combination lipid therapy in type 2 diabetes mellitus. N Engl J Med 2010, 362(17):1563-1574.

100. Parving HH, Brenner BM, McMurray JJ, de Zeeuw D, Haffner SM, Solomon SD, Chaturvedi N, Persson F, Desai AS, Nicolaides M, Richard A, Xiang Z, Brunel P, Pfeffer MA: Cardiorenal end points in a trial of aliskiren for type 2 diabetes. N Engl J Med 2012, 367(23):2204-2213. Epub Nov 3.

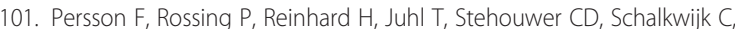
Danser AH, Boomsma F, Frandsen E, Parving HH: Renal effects of aliskiren compared with and in combination with irbesartan in patients with type 2 diabetes, hypertension, and albuminuria. Diabetes Care 2009, 32(10):1873-1879.

102. Mann JF, Anderson C, Gao P, Gerstein HC, Boehm M, Ryden L, Sleight P, Teo KK, Yusuf S: Dual inhibition of the renin-angiotensin system in high-risk diabetes and risk for stroke and other outcomes: results of the ONTARGET trial. J Hypertens 2013, 31(2):414-421.

103. Bakris GL, Oparil S, Purkayastha D, Yadao AM, Alessi T, Sowers JR Randomized study of antihypertensive efficacy and safety of combination aliskiren/valsartan vs valsartan monotherapy in hypertensive participants with type 2 diabetes mellitus. J Clin Hypertens (Greenwich) 2013, 15(2):92-100.

104. Abe M, Maruyama N, Suzuki H, Fujii Y, Ito M, Yoshida Y, Okada K, Soma M: Additive renoprotective effects of aliskiren on angiotensin receptor blocker and calcium channel blocker treatments for type 2 diabetic patients with albuminuria. Hypertens Res 2012, 35(8):874-881.

105. Scirica BM, Morrow DA, Bode C, Ruzyllo W, Ruda M, Oude Ophuis AJ, LopezSendon J, Swedberg K, Ogorek M, Rifai N, Lukashevich V, Maboudian M, Cannon CP, McCabe CH, Braunwald E: Patients with acute coronary syndromes and elevated levels of natriuretic peptides: the results of the AVANT GARDE-TIMI 43 Trial. Eur Heart J 2010, 31(16):1993-2005.

106. Ishibashi K, Kurisu S, Kato Y, Mitsuba N, Dohi Y, Nishioka K, Kihara Y: Effects of aliskiren on the fibrinolytic system in patients with coronary artery disease receiving angiotensin-converting enzyme inhibitor or angiotensin II type 1 receptor blocker. Hear Vessel 2013, 28(1):7-11.

107. Wong J: Is there benefit in dual renin-angiotensin-aldosterone system blockade? No, yes and maybe: a guide for the perplexed. Diab Vasc Dis Res 2013, 10(3):193-201.

108. Baker WL, Coleman Cl, Kluger J, Reinhart KM, Talati R, Quercia R, Phung OJ, White CM: Systematic review: comparative effectiveness of angiotensinconverting enzyme inhibitors or angiotensin II-receptor blockers for ischemic heart disease. Ann Intern Med 2009, 151(12):861-871.

109. Ravid M: Dual blockade of the renin-angiotensin system in diabetic nephropathy. Diabetes Care 2009, 32(Suppl 2):S410-S413.

110. Maione A, Navaneethan SD, Graziano G, Mitchell R, Johnson D, Mann JF, Gao P, Craig JC, Tognoni G, Perkovic V, Nicolucci A, De Cosmo S, Sasso A, Lamacchia O, Cignarelli M, Manfreda VM, Gentile G, Strippoli GF:

Angiotensin-converting enzyme inhibitors, angiotensin receptor blockers and combined therapy in patients with micro- and macroalbuminuria and other cardiovascular risk factors: a systematic review of randomized controlled trials. Nephrol Dial Transplant 2011, 26(9):2827-2847.

111. Cherney DZ, Scholey JW, Jiang S, Har R, Lai V, Sochett EB, Reich HN: The effect of direct renin inhibition alone and in combination with ACE inhibition on endothelial function, arterial stiffness, and renal function in type 1 diabetes. Diabetes Care 2012, 35(11):2324-2330.

112. Harel Z, Gilbert C, Wald R, Bell C, Perl J, Juurlink D, Beyene J, Shah PS: The effect of combination treatment with aliskiren and blockers of the reninangiotensin system on hyperkalaemia and acute kidney injury: systematic review and meta-analysis. BMJ 2012, 344:e42.

113. Makani H, Bangalore S, Desouza KA, Shah A, Messerli FH: Efficacy and safety of dual blockade of the renin-angiotensin system: meta-analysis of randomised trials. BMJ 2013, 346:f360.

114. Catala-Lopez F, Macias Saint-Gerons D: Diabetes mellitus and risks of dual blockade of the renin-angiotensin-aldosterone system. Rev Esp Cardiol 2013, 66(5):412-415.
115. St Peter WL, Odum LE, Whaley-Connell AT: To RAS or not to RAS? The evidence for and cautions with renin-angiotensin system inhibition in patients with diabetic kidney disease. Pharmacotherapy 2013, 33(5):496-514

116. Messerli FH, Bangalore S: ALTITUDE trial and dual RAS blockade: the alluring but soft science of the surrogate end point. Am J Med 2013, 126(3):e1-e3.

117. Veglio F, Puglisi E, Milan A, Mulatero P: Combinations of reninangiotensin-aldosterone system antagonists: true advantages? Curr Pharm Des 2012, 18(7):952-957.

118. CHEP: Canadian recommendations for the management of hypertension. ; 2012 Available at: URL: [http://toolkit.cfpc.ca/en/files/2012_CHEPRecsBooklet_ EN_HCP1030.pdf] Accessed May 28, 2013.

119. UK Medicines Information: What is the rationale and evidence for combining angiotensin converting enzyme inhibitors with angiotensin II receptor blockers in renal disease?. NHS 2012 January 7; Available at: URL: [https://www.evidence.nhs.uk]

120. Aliskiren Prescribing Information: Available at: URL: [http://www.accessdata. fda.gov/drugsatfda_docs/label/2012/021985s023lbl.pdf] Accessed November 16, 2012.

121. Aliskiren SmPC: EMA; 2013. Available at: URL: [http://www.ema.europa.eu/ docs/en_GB/document_library/EPAR__Product_Information/human/ 000780/WC500047010.pdf] Accessed 2013

122. EMA: Review started of combined use of renin-angiotensin system (RAS)-acting agents; 2013. May 16; Available at: URL: [http://www.emea.europa.eu/docs/ en_GB/document_library/Referrals_document/Renin-angiotensin_system_ (RAS)-acting_agents/Procedure_started/WC500143500.pdf]

123. Mallat SG: What is a preferred angiotensin II receptor blocker-based combination therapy for blood pressure control in hypertensive patients with diabetic and non-diabetic renal impairment? Cardiovasc Diabetol 2012, 11:32.

doi:10.1186/1475-2840-12-108

Cite this article as: Mallat: Dual renin-angiotensin system inhibition for prevention of renal and cardiovascular events: do the latest trials challenge existing evidence?. Cardiovascular Diabetology 2013 12:108.

\section{Submit your next manuscript to BioMed Central and take full advantage of:}

- Convenient online submission

- Thorough peer review

- No space constraints or color figure charges

- Immediate publication on acceptance

- Inclusion in PubMed, CAS, Scopus and Google Scholar

- Research which is freely available for redistribution

Submit your manuscript at www.biomedcentral.com/submit
C) Biomed Central 